Copyright (C) 2021 by Cherkas Global University

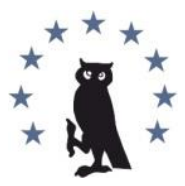

Published in the USA

Media Education (Mediaobrazovanie)

Has been issued since 2005

ISSN 1994-4160

E-ISSN 2729-8132

2021. 17(4): 585-592

DOI: $10.13187 / \mathrm{me} .2021 .4 .585$

https://me.cherkasgu.press

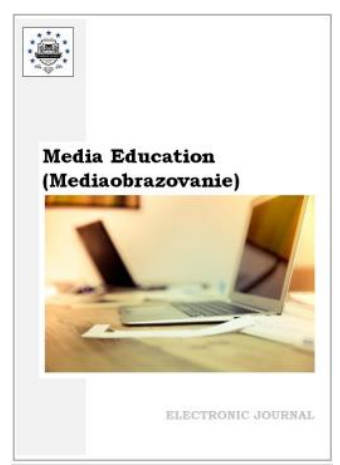

\title{
Understanding the USA through Late Night Comedy
}

Irina B. Arkhangelskaya a, b , *

${ }^{a}$ Linguistics University of Nizhny Novgorod, Russian Federation

b Lobachevski State University of Nizhny Novgorod, Russian Federation

\begin{abstract}
American late night comedy shows are a good source of information for those who would like to know more about the USA. Saturday Night Live (SNL) is the most long-lasting night comedy project on American TV, well known for its political satire and parodies. Russian viewers can watch it on many platforms nowadays: social media, online or cable TV. The goal of the research is to find out what impression $S N L$ produces on the Russian youth and how they interpret its humor. It is of interest if the show helps Russian students broaden their knowledge of the US: its politics, daily routine, key political actors, and analyze what the image of Russia and Russians in the show is. Two hundred students from Nizhny Novgorod universities took part in the survey and shared their views on US late night comedy. Ten $S N L$ 's enthusiasts were further interviewed and spoke about their likes and dislikes. The research proves that American late night comedy shows can be not only entertainment for young Russians, but useful educational material on the US politics, social life, and culture. The program might be helpful in studying English. To get better understanding of the USA students need teachers' guidance.
\end{abstract}

Keywords: late night comedy show, Saturday Night Live, SNL, American TV show, humor, laugh culture, political satire, the US media.

\section{Introduction}

Not only in the television era news were inseparable from entertainment (Postman, 2005: 83-90), in the epoch of new media people get aware of political and social agenda watching quizzes, shows, and movie series, topical comedy being one of the main sources which "adds something of its own to our understanding of current events" (Peterson, 2008: 3-4). Since 1960s, political candidates and public figures in the USA have been using late night comedy as a platform for promoting their ideas and programs, shaping or improving their images as well as fighting with their opponents. At the same time, comedians, under the masks of well-known politicians or show business celebrities, have been creating characters that have become inseparable from them.

For foreigners American late night comedy is a source of useful information that helps them catch up with the country's daily life and movements in its elite as well as improve English, if the program is watched in original.

Since 1950 o in the USA there have been many late night shows with outstanding hosts who have influenced electorate behavior and shaped political and social attitudes: Tonight Starring Jack Paar (1957-1962), The Tonight Show Starring Johnny Carson (1962-1992), Rowan \& Martin's Laugh-In (1968-1973), The Tonight Show with Jay Leno (1992-2014), Late Show with

\footnotetext{
* Corresponding author

E-mail addresses: arib@bk.ru (I. Arkhangelskaya)
} 
David Letterman (1992-2015). The Daily Show with Jon Stewart (1999-2015), The Daily Show with Trevor Noah (2015 - now) etc. NBC's Saturday Night (Saturday Night Live) or SNL (1975 now) turned out to be the most long-lasting night comedy project on American TV. Many critics consider it to be the institute that developed political satire (Kaplan, 2015), changed political campaigning in the US (Reincheld, 2006: 190), and helped "to define not generation, but multiple generations of viewers" (Saturday..., 2020: 1). The show has become a tool in political campaigns supporting democratic candidates and making fun of Republicans. Since 2010, its political activism has intensified, and it has started paying more attention to international agenda, Russia being one, though minor, themes in the program's sketches. In the era of online media, $S N L$ has provided access to its content to viewers all over the world, including the Russian public, which now has opportunities to watch the show on different platforms.

The goal of the research is to find out whether $S N L$ has fans among Russian students, what impression it produces on them and how they understand its humor. It is of interest if the show helps the Russian youth broaden their knowledge of the US: its politics, daily issues, key political actors, and what they think about the image of Russia and Russians in the show.

\section{Materials and methods}

In December 2020, 200 full-time and part-time students whose majors are Journalism or Public Relations and Advertising, from Linguistics University of Nizhny Novgorod and Lobachevski State University of Nizhny Novgorod (aged 18-24) took part in an offline or online survey that helped to reveal the 'recognizability' of the show. Those respondents, who watch SNL either in Russian or in English at least once in two weeks, were interviewed in May-June 2021 with the goal to find out what they had gained from SNL, what comedians had impressed them most, and how they evaluated "Russian theme" in the show.

The research includes analysis of those $S N L$ 's programs or episodes on YouTube platform as well as their scripts (1976-2021) that illustrate development of the show or contain satire on Russia and Russians.

Academic works as well as mass media publications on $S N L$ and late night comedy have been under scrutiny.

\section{Discussion}

Humor is a part of our life. It is with us in professional and personal relations, in education and entertainment, in literary and political discourse. However, scholars find it difficult to define the term. There is a mathematical approach to humor expressed in a formula, coined by co-founder of Russian youth humorist program KVN A.M. Akselrod: "the funny = recognizable + the unexpected" (Akselrod et al, 1974). 'Recognizable' means that the 'laughter users' in order to understand a joke, especially in sphere of politics, should get insight into the "local context", know "local norms, paradoxes, and taboos", as well as "social inequalities and power relations" of the society (Swinkels, Koning, 2016: 8). Thus, it is often difficult to get into the subtleties of a foreign laugh culture, which demands knowing the background, personas, current problems, and approaches to conflict resolution. We should also take into account «the audience is formed by its social, cultural, and political perspectives and beliefs, which are often very different or even conflicting» (Fedorov, Levitskaya, 2020: 238). We may classify political gags according to metaphors they apply (Droog et al, 2020), but not all metaphors can be deciphered on a global level, some of them are for local consumption.

Satire is a part of the political discourse in democratic societies (Ödmark, Harvard, 2021; Higgie, 2017). For that reason, comedy shows are important means of communication that help the elite and the public understand each other. Foreigners may learn about the country and its people by watching comedy programs.

$S N L$ is a program for American public, but recently has received international recognition. In Russia, the audience has access to the show via You Tube, social media (VKontakte, Facebook), or online cinema services (Kinopoisk, kino.mail.ru, or film.ru). On Kinopoisk Russian viewers characterize $S N L$ as "hilarious... and reasonably cheesy", and 6,020 viewers rated the show 8, 372 out of 10 (Saturday Night Live, serial 1975 - 2001).

The show has a long history. In 1975, 30-year-old Canadian writer and comedian, later producer, Lorne Michaels and 28-year-old NBC executive Dick Ebersol launched the program on NBC. They set a 90-minute protocol for the show with sketches, musical performances, and parody 
on news broadcast Weekend Update. A celebrity guest, the key person of the program, usually takes part in sketches with the cast, and musical performances has always been its important part. The show has made fun of many politicians, and at the same time helped some of them communicate with the audience and fight for electorate. It has always supported Democratic Party and promoted liberal values.

Many scholars pay attention to the fact that the satire in $S N L$ has political and social character (Young, 2019: 17), but there is an opinion that the show's Weekend Update is a factory of "fake news" (Day, Thomson, 2012: 4) which creates caricatures on political actors and spreads made up stories destroying reputations and demonizing politicians. In publications, which focus on potential persuasive effects of social and political humor (Nabi et al., 2007), there is no solidarity on whether American TV humor influences political behavior, shapes views, or helps in understanding different US internal or external issues. Some scholars are sure that parodies and comic gags may build up or destroy reputations and affect the electorate choice (Baumgartner, 2013; 2021, Baumgartner et al., 2019). They may also inform the viewers or manipulate them.

Political parody started on $S N L$ in 1976, before presidential elections, when the 23-year-old Dan Aykroyd, who played kindhearted Jimmy Carter (Democratic candidate), and Chevy Chase, parodying Gerald Ford (Republican, the US president), in series of humorous duels debated on different issues: economics, life style, and even the manner of dressing ( $S N L$, season 2, October 16, 1976). The sketches attracted TV viewers and the program's rating went up. SNL portrayed G. Ford as an incompetent president, but promoted his opponent. The format was a success, and since then political parody has become an inseparable part of the show (Peifer, Landreville. 2020). Moreover, Gerald Ford appeared in the show in person trying to attract the young audience and change their attitude to him. Having lost elections, he questioned whether it was worth taking part in the show, but later concluded that the decision was the right one (Brownell, 2016: 939). SNL's impersonations of Gerald Ford, Bill Clinton, two George Bushes, Sarah Palin, and recently Donald Trump and Joe Biden have become a part of political theatre on TV and later in social media outlets.

In 1970 - 1980s $S N L$ was concentrated mainly on entertainment, and politics was not its focal point. In 1990s, late night comedy programs became highest-rated. Many comedy show hosts, David Letterman being one of them, understood that the road to the White House ran through them (Lichter et al., 2014: 2), and with that feeling they selected guests to their programs. Comedy format attracted politicians who were looking for the chance to present themselves and their programs in an informal manner. Since 1990s, participation in late night comedy programs has become a part of political campaigning and image building. SNL has invited politicians and celebrities to have their say, but parody remained its non-changing feature.

In 1970 - 1990s, SNL's political jokes, though biased, were bold, topical and not insulting. Covering Bill Clinton and Monica Lewinski affair $S N L$ comedians dared to assume that attacking Iraq was a chance to distract the attention of the public from the sexual scandal ( $S N L$, season 23, Feb., 28, 1998). At the same time, they did not offend anybody, SNL's writers and comedians did their best "to find the statement that was within the standards of taste" (Reincheld, 2006: 194). However, in 2000 s humor on $S N L$ has turned to be overall pro-democratic, Republican presidential candidates have been targeted with greater frequency than Democratic candidates (Lichter et al., 2014). Since 2010, SNL's parodies have become evil lampoons, sometimes 'killing jokes' that meant to denigrate or demonize public officials, political actors, or even countries. The comedians laughed at George Bush, Sara Palin, and later Donald and Melania Trump. SNL's political satire annoyed President Trump, and he expressed his anger in Twitter, thus attracting more attention to parodies on him (Becker, 2018; Scacco et al., 2020).

Many Russians have been interested in American politics, lifestyle and culture. With the collapse of the USSR, American movies and TV shows have become a source of knowledge about the USA for Russian people. In 2005, MTV Russia broadcasted SNL series under the name Saturday fever ("Subbotnyaya likhoradka"); the project did not last long, but made the show known in Russia. In 2013 there was an attempt to create a Russian analogue of SNL on NTV channel (NTV..., 2013; Kitaeva, 2013), but the project was not successful. For more than a decade, Russians have had an opportunity to watch $S N L$ on YouTube or online home cinema services.

$S N L$ 's comedians have shown Russia mainly in negative context. President Vladimir Putin has been impersonated on SNL nine times: once in 2000 by Will Ferrell, and in 2016-2017 by Beck 
Bennett. The first sketch was neutral, but other eight - insulting for the Russian leader. However, the fact that the show is Russophobic has not distracted Russian fans from watching it.

In 2013, SNL introduced a new character (Kate McKinnon), a Russian correspondent on Weekend Update, who comes from a remote Ural village where there are no traces of civilization, bears are walking along the streets, and wolves are chasing lonely girls at night. She tells Seth Meyers about the recent meteor explosion near her home as well as misery, poverty and hunger (SNL, season 38, Feb. 16., 2013), expresses surprise that someone from the West is visiting Russia on Sochi Olympiad event (SNL, season 39. Jan. 21, 2014), compares District 12 from The Hunger Games to the richest neighborhood in her village (SNL, season 40, March 28, 2015). Olya is a caricature depicted in a Western tradition of showing Eastern European women with "stereotypical notions of otherness" (Wiedlack, 2019: 1066). She is an aborigine from horrible and disastrous Russia where nobody would like to live. Russian and Soviet movies as well as TV shows may also present the Western world as gloom and doom (Fedorov, 2017).

President V. Putin, parodied by Beck Bennett, appears in $S N L$ as a bare-chested dictator, his role in all episodes is to diminish Donald Trump and declare him a Russian marionette. On January 2017, the RF President (Beck Bennett) confesses that Russians made "Donald Trumb $45^{\text {th }}$ president of the United States" and adds that it was the most expensive thing Russians had ever bought $(S N L$, season 42, Jan. 21, 2017). Putin is a media stereotype with schematic and stable features (Fedorov, 2015: 158): president-tsar, aggressive, cynical and respecting only strength. That is how the Western mass media often shows him.

After Donald Trump's defeat in presidential elections, SNL comedians have practically lost their interest in Russia.

Nevertheless, SNL's Russian audience has been increasing in YouTube and streaming services; Many Russian scholars, political analysts, and students have signed for SNL's page on Facebook.

\section{Results}

In December 2020, a month after the USA presidential elections, 200 students, whose majors are Journalism, Public Relations and Advertising, from Linguistics University of Nizhny Novgorod and Lobachevski State University of Nizhny Novgorod took part in the survey. It aimed to reveal those who are interested in the US events and watch American late night comedy shows, SNL being in the list.

Answering the questionnaire, students confessed that got information about the US from different sources; social media were the priority for them.

Table 1. Respondents' answers to the question: "Where do you get information about the USA?" (more than one answer was possible)

\begin{tabular}{|lc|}
\hline Source of information & $\mathbf{\%}$ \\
\hline From social media & $72.2 \%$ \\
\hline News feeds & $55.6 \%$ \\
\hline Russian TV news & $44.4 \%$ \\
\hline Western TV news & $15.5 \%$ \\
\hline Not interested in the US issues & $14.6 \%$ \\
\hline
\end{tabular}

At that post-elections period of December 2021 Donald Trump remained President of the country: Joe Biden's inauguration was scheduled for January. Nevertheless, 130 students from all the respondents were sure that Jo Biden was President. That proves that students' knowledge of the current situation in the USA is superficial.

Table 2. Respondents' answers to the question: "Who is the current US President?"

\begin{tabular}{|l|c|}
\hline The US President is & $\mathbf{\%}$ \\
\hline Joe Biden & $33 \%$ \\
\hline Donald Trump & $65 \%$ \\
\hline No answer & $2 \%$ \\
\hline
\end{tabular}


170 respondents ( $89.5 \%$ out of 200) have watched US late night comedy shows, full program or episodes, more than once in their life. $78.9 \%$ from 170 prefer to watch American comedy shows in English, $21.1 \%$ in Russian, and 10.1\% - in English with Russian captions (subtitles). 50 students (27.8 \% out of 170) watch Saturday Night Live (a full program or episodes) at least once a month. 200 respondents are sure that it is possible to see late night US shows in many platforms.

Table 3. Respondents' answers to the question: "Where can you watch late night US comedy show?" (more than one answer was possible)

\begin{tabular}{|c|c|}
\hline $\begin{array}{l}\text { Where you can watch late night US } \\
\text { comedy shows }\end{array}$ & $\%$ \\
\hline YouTube & $94.7 \%$ \\
\hline Social media groups (VKontakte, Facebook) & $47.7 \%$ \\
\hline Online cinema theaters & $21.1 \%$ \\
\hline Cable or satellite TV & $15.8 \%$ \\
\hline I do not know & $5.3 \%$ \\
\hline
\end{tabular}

$27.9 \%$ of respondents out of all, who love American humor programs, highly appreciated Saturday Night Live. That group of students, most of them from Nizhny Novgorod Linguistic University, love SNL, South Park (Comedy Central, in Russia - channel "2x2"), and The Late Show with Stephen Colbert (CBS). They prefer shows in original as it helps them improve their knowledge of English.

Ten students, who watch $S N L$ at least once in two weeks, agreed to share their impressions on episodes of different periods in May - June 2021. There were no obligations on what content to consume, but there was a suggestion to think on how Russia is presented in the show.

Eight students out of ten were from Nizhny Novgorod Linguistic University, they estimated their knowledge of English as intermediate or upper intermediate. Six of them prefer to watch the show in English with captions. Two of the interviewees, who have had experience of living and studying in the USA, prefer to watch the show in English without captions. Two students from Lobachevski State University conduct research on the US journalism or political campaigning, they read a lot in English but cannot understand comedy sketches in English and watch the show in Russian.

Eight students find the show hilarious, and two - controversial as they assume that some parodies are vulgar.

Interviewees have named the following impersonations as the most memorable:

- Donald Trump (Alec Baldwin) - 10 students.

- Joe Biden (Jim Carrey) - 8 students

- Hillary Clinton (Kate McKinnon) - 6 students

- Kim Jong Un ( students could not recall the name of the actor) - 2 students

- President Putin (Beck Bennett) - 2 students

- Eminem (Stu) in Christmas program on December 6, 2020 - Stan (Pete Davidson) 2 students.

All ten students marked the program on May 8, 2021, which Elon Musk hosted, as very special. The respondents think that the CEO of Tesla and founder of SpaceX is an outstanding person with a good sense of humor ( $S N L$, season 46, May 08, 2021). They enjoyed his jokes and admired his mother who assisted Elon in the show.

Alec Baldwin's parody on Donald Trump was highly estimated. Students think that the actor have succeeded in portraying the President and managed to catch some specific features of the politician.

Only two students saw episodes with 'President Putin "Beck Bennett”. The opinions on them are different - 'laughable' and 'disgusting'.

Two students mentioned episodes with Olya Polatovskaya (Kate McKinnon) and confessed that though the sketches were weird and full of anti-Russian sentiments, nevertheless, they laughed watching them.

When asked to describe in a free form their impressions of $S N L$ the respondents mentioned that they learnt a lot about the US from the show, and all students, even those who watch the show in Russian, said that it was an opportunity to improve English language skills. 
Table 4. Interviewees' answers to the question: "Why do you like $S N L$ ?" (more than one answer was possible)

\begin{tabular}{|l|l|}
\hline \multicolumn{1}{|c|}{ Why do you like SNL? } & Number of students \\
\hline Good entertainment & 10 \\
\hline Useful information about the US & 8 \\
\hline Good way to improve your English & 8 \\
\hline Good music & 7 \\
\hline You meet celebrities and get to know more about them & 6 \\
\hline Example of democracy: you may laugh at political leaders & 2 \\
\hline
\end{tabular}

Students think that they get some useful information about the US from the show. However, they cannot understand the sketches, which show Senate or Supreme Court hearings. Even those who write a paper about images of Ruth Ginsberg and Sandra Day O'Connor, outstanding womenjudges of the Supreme Court, do not get the essence of $S N L$ 's jokes devoted to scandalous Congress testimony of Brett Kavanaugh, Supreme Court justice nominee, accused of sexual misconduct (SNL, Season 44, Sep. 29.2018). Neither can those interested in American Studies get into the subtleties of $S N L$ 's humor on BLM fight or Senate hearings on political issues as they lack basic knowledge on the US government and politics. Teachers' commentaries might be of help in analyzing those materials.

Interviewees would love to see more parodies on show business celebrities as well as musical episodes in the show. They enjoy political satire and consider it a feature of real democracy. However, students think that sometimes SNL's political parodies are tasteless.

All students agree that professional comments or additional reading would make understanding of the show's humor easier.

\section{Conclusion}

American late night comedy shows have always been not only entertainment but also a source of knowledge about the current events in the USA. Most of them pay special attention to politics and even form electorate's attitudes and behavior.

Saturday Night Live, the most long-lasting night comedy project on American TV, is popular with those young Russians who try to catch up with international news and enjoy American laugh culture. They may watch the program on social media, first, YouTube, or online-cinema platforms. Only $5 \%$ of 200 respondents watch the show on a regular basis at least once in two weeks.

The research proves that $S N L$ helps the Russian youth in broadening their knowledge of the US politics, social life, but students do not get the sense of some sketches and gags because they are not well enough aware of American government structure as well as the process of decision-making on different levels. In order to get better understanding of the program content students need professional commentaries. Parodies on candidates fighting for opening positions in the US Supreme Court are of no interest to the students, as they have no clue about the role of this institute.

The respondents' favorite impersonators are Alec Baldwin as Donald Trump, Joe Biden as Jim Carrey, and Kate McKinnon as Hillary Clinton: all of them are popular political actors in Russia.

$S N L$ provides good material for analysis, but students need to apply critical thinking while being acquainted with its content. Some of the interviewees do not approve of evil lampoons on Russia, but there are students who find them hilarious. It is very important to analyze in research projects how Russia is presented in comedy shows and whether jokes and gags are a part of information wars.

Comedy programs, like $S N L$, might help in mastering English and can be a part of special courses on American government and politics, media and culture. There are many approaches to studying the USA as well as trying to figure out how Americans view Russia and Russians, and one is via the country's late night humor. 


\section{References}

Akselrod et al., 1974 - Akselrod, A., Kandror, M., Levinton, M. (1974). Kurs veselykh nauk [Course in the Merry Sciences]. Moscow. [Electronic resource]. URL: https://libking.ru/books/ humor-/humor/521075-28-albert-akselrod-kurs-veselyh-nauk.html\#book [in Russian]

Baumgartner, 2013 - Baumgartner, J.C. (2013). No laughing matter? Young adults and the 'spillover effect' of candidate-centered political humor. Humor - International Journal of Humor Research. 26(1): 23-43. DOI: 10.1515/humor-2013-0003

Baumgartner, 2021 - Baumgartner, J.C. (2021) Is It Funny if No One is Watching? Public Response to Late-Night Political Satire.Comedy Studies. 12(1): 15-28. DOI: 10.1080/ 2040610X.2020.1850101.

Baumgartner et al., 2019 - Baumgartner J.C, Lichter S.R., Morris J.C. (2019). Research note: negative news and late-night comedy about presidential candidates. Humor - International Journal of Humor Research. 32(4): 605-617. DOI: 10.1515/humor-2018-0067

Becker, 2018 - Becker, A. (2018). Live from New York, It's Trump on Twitter! The Effect of Engaging With Saturday Night Live on Perceptions of Authenticity and the Salience of Trait Ratings. International Journal of Communication: 12: 1736-1757. [Electronic resource]. URL: https://ijoc.org/index.php/ijoc/article/view/8626/2326

Brownell, 2016 - Brownell, K.C. (2016). The Historical Presidency: Gerald Ford, Saturday Night Live, and the Development of the Entertainer in Chief. Presidential Studies Quarterly. 46(4): 925-942. DOI: 10.1111/psq.12326

Day, Thompson, 2012 - Day A., Thompson, E. (2012). Live From New York, It's the Fake News! Saturday Night Live and the (Non) Politics of Parody. Popular Communication. The International Journal of Media and Culture. 10(1-2): 170-182. DOI: 10.1080/15405702.2012.638582

Droog et al., 2020 - Droog, E., Burgers, C., Steen, G. (2020). How satirists alternate between discursive modes: an introduction of the humoristic metaphors in satirical news (HMSN) Typology. International Journal of Communication. 14: 3964-3985. [Electronic resource]. URL: https://ijoc.org/index.php/ijoc/article/view/13963/3163

Fedorov, 2015 - Fedorov, A. (2015). Media stereotypes analysis in the classroom at the student audience. European Journal of Contemporary Education. 12(2): 158-162. DOI: 10.13187/ ejced.2015.12.158

Fedorov, 2017 - Fedorov, A. (2017). The Western World in Soviet and Russian Cinema (19462016). Russian Education and Society. 59(7-9): 319-464. DOI: 10.1080/10609393.2017.1413880

Fedorov, Levitskaya, 2020 - Fedorov, A., Levitskaya, A. (2020). Pseudo-Chomsky or Media Manipulation in the Scientific Area. Media Education. 60(2): 238-245. DOI: 10.13187/me. 2020.2.238

Higgie, 2017 - Higgie, R. (2017). Public engagement, propaganda, or both? Attitudes toward politicians on political satire and comedy programs. International Journal of Communication. 11: 930-948. [Electronic resource]. URL: https://ijoc.org/index.php/ijoc/article/view/5675/1944

Kaplan, 2015 - Kaplan, A. (2015). Saturday Night Live: Shaping TV Comedy and American Culture. NY: 21st Century Books: 64.

Kitaeva, 2013 - Kitaeva, K. (2013). Vechernego Urganta malo [Late Night Urgant is not Enough]. RBK. 11.06.2013. [Electronic resource]. URL: https://www.rbc.ru/newspaper/2013/ 06/11/56c1a1649a7947406eao9a34 [in Russian]

Lighter et al., 2014 - Lighter, R.S., Baumgartner, J.C., Morris, J.S. (2014). Politics Is a Joke!: How TV comedians are remaking political life. NY: Routledge: 272. DOI: 10.4324/97804 29493294

Nabi et al., 2007 - Nabi, R.L., Moyer-Gusé, E., Byrne, S. (2007). All joking aside: A serious investigation into the persuasive effect of funny social messages. Communication Monographs. 74(1): 29-54. DOI: 10.1080/03637750701196896

NTV..., 2013 - NTV zapuskaet sobstvennuyu adaptatsiyu Saturday Night Live [NTV Launches its own adapted version of Saturday Night Live]. (2013). Medianyanya. 12.06.2013. [Electronic resource]. URL: https://mediananny.com/novosti/2299907/NTV_zapuskaet_sobs tvennuju_adaptatsiju_Saturday_Night_Live\#[in Russian]

Ödmark, Harvard, 2021 - Ödmark, S., Harvard, J. (2021). The democratic roles of satirists, Popular Communication. The International Journal of Media and Culture. [Electronic resource]. URL: https://www.tandfonline.com/doi/full/10.1080/15405702.2021.1929995? scroll=top \&needAccess=true. DOI: 10.1080/15405702.2021.1929995 
Peifer, Landreville, 2020 - Peifer, J., Landreville, K. (2020). Spoofing Presidential Hopefuls: The Roles of affective disposition and positive emotions in prompting the social transmission of debate parody. International Journal of Communication. 14: 200-220. [Electronic resource]. URL: https://ijoc.org/index.php/ijoc/article/view/11439/2904

Peterson, 2008 - Peterson, R.L. (2008). Strange Bedfellows: How Late-Night Comedy Turns Democracy into a Joke. New Brunswick, New Jersey: Rutgers University Press: 280.

Postman, 2005 - Postman, N. (2005). Amusing ourselves to death: public discourse in the age of show business. NY: Penguin Books: 208.

Reincheld, 2006 - Reincheld, A. (2006). Saturday Night Live and Weekend Update: The formative years of comedy news dissemination. Journalism History . 31(4): 190-197.

Saturday..., 1975-2001 - Saturday Night Live, series 1975-2001). [Electronic resource]. URL: https://www.kinopoisk.ru/series/400753

Saturday Night Live and Philosophy, 2020 - Saturday Night Live and Philosophy: Deep Thoughts through the Decades (2020). Wiley-Blackwell: 272.

Scacco et al., 2020 - Scacco, J., Copeland, L., Becker, A., Berger, J. (2020). When the President Tweets: Exploring the normative tensions of contemporary presidential communication. International Journal of Communication. 14: 3119-3142. [Electronic resource]. URL: https://ijoc.org/index.php/ijoc/article/view/13193

SNL, 1976 - SNL, season 2, October 16, 1976. [Electronic resource]. URL: https://www. youtube.com/watch?v=xu2vdEoz7ds

SNL, 1998 - SNL, season 23, Feb. 28, 1998. [Electronic resource]. URL: https://www. youtube.com/watch?v=pVfUvwb167Q

SNL, 2000 - SNL, season 25, Jan 08, 2000. [Electronic resource]. URL: https://www. youtube.com/watch?v=j930ZwNkHhQ

SNL, 2013 - SNL, season 38, Feb.16, 2013. [Electronic resource]. URL: https:/www. youtube.com/watch?v=8Kz5l2mRvmY

SNL, 2014 - SNL, season 39. Jan. 21, 2014. [Electronic resource]. URL: https://www. youtube.com/watch?v=hL-jAGcokiU

SNL, 2015 - SNL, season 40, March 28, 2015. [Electronic resource]. URL: https://www. youtube.com/watch?v $=130 x m S B u Y w c$

SNL, 2017 - SNL, season 42, Jan. 21, 2017. [Electronic resource]. URL: https://www. youtube.com/watch?v=LNK430YOiT4

SNL, 2018 - SNL, season 44, Sep. 29.2018. [Electronic resource]. URL: https://www. youtube.com/watch?v=VRJecfRxbr8

SNL, 2020 - SNL, season 46, Dec. 06, 2020. [Electronic resource]. URL: https://www. youtube.com/watch?v=1OJ7aW3Df5U (

SNL, 2021 - SNL, season 46, May 08, 2021. [Electronic resource]. URL: https://www. youtube.com/watch?v=fCF8I_X1qKI

Swinkels, Koning, 2016 - Swinkels, M., Koning, A. (2016). Humour and anthropology. Etnofoor. 28(1): 7-10.

Wiedlack, 2019 - Wiedlack, K. (2019). In/visibly different: Melania Trump and the othering of Eastern European women in US culture. Feminist Media Studies. 19(8): 1063-1078. DOI: 10.1080/14680777.2018.1546205

Young, 2019 - Young, D.G. (2019). Irony and Outrage: The Polarized landscape of rage, fear, and laughter in the United States. NY: Oxford University Press: 288. DOI: 10.1093/oso/ 9780190913083.001.0001 